\title{
Hemoglobin Level and Total Leukocyte Differential in Laying Hens Fed with Betel Leaf Juice (Piper betle Linn)
}

\author{
Ning Ayu Dwi Tiya ${ }^{1}$, Rusli Badaruddin², Muh Akramullah ${ }^{1}$, Ali Bain², Natsir Sandiah² \\ ${ }^{1}$ Alumnus of Animal Husbandry Production and Technology Study Program, Postgraduate Department, Insitut \\ Pertanian Bogor, Bogor, Indonesia. \\ ${ }^{2}$ Lecturer of Animal Husbandry Department, Faculty of Animal Husbandry, Universitas Halu Oleo, Kendari, \\ Indonesia. \\ *Email correspondence: rbadaruddin79@gmail.com
}

\begin{abstract}
Article Info

Volume 8 Issue 2

Page Number: 81-86

Publication Issue :

March-April-2021

\section{Article History}

Accepted : 10 March 2021

Published : 19 March 2021

This research aims to examine the hemoglobin level and the total leukocyte differential in the blood of laying hens fed with different levels of betel leaf juice (Piper betle Linn). There were 32 laying hens in layer phase. The cage used is an individual cage equipped with a place for feeding and drinking water. The treatments in this research consisted of: (P0) drinking water $+0 \mathrm{ml}$ of betel leaf juice, (P1) drinking water $+5 \mathrm{ml}$ of betel leaf juice, (P2) drinking water $+10 \mathrm{ml}$ of betel leaf juice, and (P3) drinking water $+15 \mathrm{ml}$ of betel leaf juice. The variables observed were hemoglobin level, leukocyte differential (lymphocytes, heterophils, monocytes, eosinophils and basophils) and the heterophils / lymphocyte ratio (H/L). The data obtained were analyzed using analysis of variance and then continued with Duncan's multiple range test. The results showed that the addition of betel leaf juice had no significant effect ( $p>$ 0.05) on the levels of hemoglobin, lymphocytes, heterophils, monocytes, eosinophils, basophils and the H/L ratio of laying hens' blood. Based on the results of the research, it can be concluded that the addition of betel leaf juice at different levels does not affect the levels of hemoglobin, lymphocytes, heterophils, monocytes, eosinophils, basophils and the H/L ratio of laying hens' blood, but these conditions are still in normal physiological conditions.

Keywords : Betel Leaf, Hemoglobin, Laying Hen, Leucocyte Differential
\end{abstract}

\section{INTRODUCTION}

Blood has an important function to support the metabolism of the body, namely to transport oxygen, carbon dioxide, nutrients in feed, and the remains of the metabolism (Harper et al. 1979). In addition, blood can be used as a parameter of immune system that determines animal health status (Mulyadi, 2015). Blood hematology tests that are often used to measure the health status of animals are the number of erythrocytes, hemoglobin levels, and total leukocyte differential in blood (Gerardo et al. 2009). 
Hemoglobin is a compound resulted from the complex bonds between protein and iron $(\mathrm{Fe})$ which cause red color in blood. Hemoglobin is produced by red blood cells synthesized from acetic acid and glycine producing porphyrin (Rastogi 1977). The function of hemoglobin is to transport oxygen $\left(\mathrm{O}_{2}\right)$ from the lung to all body cells, and to carry carbon dioxide $\left(\mathrm{CO}_{2}\right)$ back to the lung (Oppusunggu 2009). In addition, hemoglobin has a function to bind oxygen to meat, causing the bright color of the meat.

Leukocyte differential can provide animal health status and overview (Isroli et al. 2009). Cahyaningsih et al. (2007) stated that leukocyte differential is a unit of white blood cells consisting of two groups, namely granulocyte group consisting of heterosinophils, eosinophils, and basophils, and agranulocyte group consisting of lymphocytes and monocytes.

Generally, breeders use antibiotics to keep the physiological condition of chicken normal, but this method is considered less safe because antibiotics can produce residues in the meat. In addition, long-term use of antibiotics can cause bacteria or viruses to mutate and become immune.

Based on this explanation, it is necessary to make some efforts to produce healthy livestock products, one of which is by using herbal plants as livestock feed. The herbal plant used in this research is betel leaf extract. Betel is a kind of vine and creeper with a height of 5-15 m depending on the growth and the place. Parts of the betel plant (Pipper betle Linn.) such as roots, seeds, and leaves have potential for medicinal purposes, but the most frequently used is the leaf (Damayanti and Mulyono 2003). The chemical content contained in betel leaves are saponins, flavonoids, polyphenols, and astari oil. Saponin compounds can work as antimicrobials and flavonoids in betel leaf have a function as antioxidants (Carolia and Noventi 2016). According to Pahlepi et al. (2015), the essential oil content in betel leaf functions as a botanical fungicide and antifungal. This chemical content is expected to improve the health of laying hens, resulting in hemoglobin and leukocyte differentials within the normal range.

The purpose of this research is to determine the hemoglobin level and the total leukocyte differential in the blood of laying hens fed with different levels of betel leaf juice (Piper betle Linn).

\section{MATERIALS AND METHODS}

\section{Research Time and Location}

This research was done in 16 weeks from October 2020 to December 2020 at Poultry Cage Unit of Animal Husbandry department, faculty of Animal Husbandry, Universitas Halu Oleo, Kendari.

\section{Research Materials}

The material used in this research was 32 laying hens in the layer phase. The cage used was an individual cage equipped with a place for feeding and drinking water. Each cage plot is $40 \mathrm{~cm}$ long, $30 \mathrm{~cm}$ wide and $37 \mathrm{~cm}$ high.

\section{Research Procedures}

\section{a. Research preparation}

The experimental animal used was laying hens aged 35 weeks with an average weight of $1.7 \mathrm{~kg}$. Before collecting the research data, the chickens were accustomed to the experimental conditions for 14 days and were given adequate standard food and drinks.

\section{b. The making of betel leaf juice}

100 grams of fresh betel leaves are first washed thoroughly, cut into chunks, and blended for 10 minutes with $400 \mathrm{ml}$ of distilled water, then mixed in drinking water according to the treatment level.

\section{c. The giving of betel leaf juice}

Laying hens in this research were divided into four treatments; each treatment consists of 4 replications 
and each replication consists of 2 chickens. The treatments in this research consisted of: (P0) drinking water $+0 \mathrm{ml}$ of betel leaf juice, (P1) drinking water + $5 \mathrm{ml}$ of betel leaf juice, (P2) drinking water $+10 \mathrm{ml}$ of betel leaf juice, and (P3) drinking water $+15 \mathrm{ml}$ of betel leaf juice.

Control treatment (without betel leaf juice) and betel leaf juice are given through drinking water, twice a day, namely in the morning at 07:00 WITA (Central Indonesian Time) and evening at 16:00 WITA.

\section{d. Feeding}

Feed is given twice a day, namely in the morning at 07:00 WITA and in the afternoon at 16:00 WITA. The composition of the feed ingredients used consisted of $50 \%$ milled corn, $15 \%$ rice bran, and RK-234 concentrate produced by PT. Charoen Phokphand as much as $35 \%$ with a feed protein content of $18 \%$.

\section{e. Hemoglobin Level Determination}

Before giving the treatment to the experimental animals, domestic chickens were fasted for 16 hours to stabilize hemoglobin levels from the effects of feeding. Hemoglobin level measurement was calculated using ACCUPRO. Firstly, the ACCUPRO was switched on by pressing the "on" button, then a hemoglobin chip and hemoglobin strip were attached to the ACCUPRO device. Blood was drawn through Vena brachialis (wing) and then dripped on ACCUPRO. Within 5 seconds, the blood hemoglobin level would be measured automatically and the results can be read on the ACCUPRO monitor.

\section{f. Leukocyte Differential Test}

Leukocyte differential was measured by making a preparation sample of blood about two $\mathrm{cm}$ from the end of the slide. The preparation was rubbed and fixed using $75 \%$ of methanol for 5 minutes. After that, it was lifted to dry in the air. The blood swab was given a solution of giemsa for 30 minutes, then removed and washed using running water to remove excess dye, then dried with blotting paper. The swab preparation was placed under a microscope of $1000 \mathrm{x}$ magnification and added with emersion oil. Next, lymphocytes, heterophils, monocytes, eosinophils and basophils were counted with a magnification of 1000 times to a total number of 100 leukocytes.

\section{Data Analysis}

The analysis of data obtained was processed using variance in accordance with Completely Randomized Design (CRD) and if the treatment had a significant effect, it would be further tested using Duncan's Multiple Area Test (Gaspersz 1994).

\section{RESULTS AND DISCUSSION}

\section{Hemoglobin Level}

The analysis results of the hemoglobin status of laying hens fed with different levels of betel leaf juice are presented in Table 1.

Table 1. Hemoglobin value of laying hens fed with different levels of betel leaf juice

\begin{tabular}{cc}
\hline Treatment & Hemoglobin $(\mathrm{g} / \mathrm{dL})$ \\
\hline P0 & $14.60 \pm 1.19$ \\
P1 & $13.82 \pm 3.81$ \\
P2 & $13.24 \pm 1.61$ \\
P3 & $14.98 \pm 1.79$ \\
\hline
\end{tabular}

The results of the variance analysis showed that the giving of betel leaf juice had no significant effect ( $p$ $<0.05$ ) on the blood hemoglobin levels of laying hens. The hemoglobin level of laying hens in this research was 13.24-14.98 $\mathrm{g} / \mathrm{dL}$. This range is still in the normal category. According to Samour (2015), the normal range of hemoglobin levels of chickens is around $10.20-15.10 \mathrm{~g} / \mathrm{dL}$.

The normal condition of hemoglobin in this research indicated that betel leaf juice did not contain toxic substances that could cause the formation of red blood cells to be disrupted or erythrocytes to lysis. The amount of hemoglobin in the normal range 
indicated that laying hens had enough oxygen for the body's metabolic processes. According to Syahrial et al. (2013), hemoglobin is a reflection of the supply of oxygen in the blood circulation in living things.

\section{Leukocyte Differential}

The differential values of leukocytes (lymphocytes, heterophils, monocytes, eosinophils and basophils) and the heterophils/lymphocyte ratio $(\mathrm{H} / \mathrm{L})$ of laying hens' blood are presented in Table 2 .

Lymphocytes are immune cells that play a role in specific immune responses. The specific immune response is mediated by $\mathrm{B}$ lymphocytes ( $\mathrm{B}$ cells) and $\mathrm{T}$ lymphocytes ( $\mathrm{T}$ cells). B cells play a role in Humoral Mediated Immunity (HMI), which produces antibody products (immunoglobulins). $\mathrm{T}$ cells play a role in Cellular Mediated Immunity (CMI) (Nicholas 2004).
Heterophils are a key component of the innate immune system, which acts like neutrophils in mammals (Chuammitri et al. 2011). Heterophils have a function as phagocytic cells or phagocytosis (ingest pathogens) of bacteria, parasites and viruses (Akramullah 2020).

Monocytes are the second defense in the body after heterophils, when inflammation occurs, monocytes microscopy to tissues and turn into macrophages (Mitchell and John 2008). Monocytes also have the same function as heterophils in term of phagocytosis of disease agents (Akramullah 2020). When migrating to the tissue and turning into active macrophages, they act as phagocytic cells (Wibawan and Soejoedono 2013).

Table 2. Leukocyte differential and the heterophils/lymphocyte ratio $(\mathrm{H} / \mathrm{L})$ in the blood of laying hens fed with different levels of betel leaf juice

\begin{tabular}{|c|c|c|c|c|c|}
\hline \multirow{2}{*}{ Variable } & \multicolumn{4}{|c|}{ Treatment } & \multirow{2}{*}{ Standard } \\
\hline & P0 & $\mathrm{P} 1$ & P2 & P3 & \\
\hline \multicolumn{6}{|c|}{ Leukocyte Differential } \\
\hline Lymphocytes & $60.67 \pm 3.74$ & $62.45 \pm 4.41$ & $61.72 \pm 3.10$ & $62.39 \pm 2.65$ & ${ }^{1} 45.00-70.00$ \\
\hline Heterophils & $27.04 \pm 4.18$ & $26.56 \pm 5.13$ & $27.55 \pm 3.10$ & $27.25 \pm 2.09$ & ${ }^{1} 15.00-40.00$ \\
\hline Monocytes & $6.69 \pm 0.82$ & $6.73 \pm 0.89$ & $7.43 \pm 0.82$ & $7.33 \pm 0.34$ & $15.00-10.00$ \\
\hline Eosinophils & $5.36 \pm 1.69$ & $4.26 \pm 1.68$ & $3.30 \pm 1.09$ & $3.02 \pm 1.17$ & ${ }^{1} 1.50-6.00$ \\
\hline Basophils & $0.25 \pm 0.50$ & $0.00 \pm 0.00$ & $0.00 \pm 0.00$ & $0.00 \pm 0.00$ & ${ }^{2} 0.00-0.60$ \\
\hline H/L Ratio & $0.45 \pm 0.09$ & $0.43 \pm 0.12$ & $0.45 \pm 0.07$ & $0.44 \pm 0.05$ & ${ }^{3} 0.20-0.80$ \\
\hline
\end{tabular}

${ }^{1}$ Jain (1993); ${ }^{2}$ Coles (2006); ${ }^{3}$ Emadi et al. (2007);

Eosinophils are part of leukocytes that play an active role in helping to regulate the severity of allergies or to kill a number of parasites that infect the body (Arjuna et al. 2019).

Basophils play an important role in the immune response which begins with contact with substances causing allergies by producing chemical mediators such as histamine which in turn attract other immune cells (Moreira 2013).
The results of the variance analysis showed that the giving of betel leaf juice had no significant effect ( $>0.05)$ on the differential value of leucocytes (lymphocytes, heterophils, monocytes, eosinophils and basophils) in laying hens' blood. The differential value of leukocytes resulted in this research is still in normal levels (Jain 1993; Coles 2006). It is suspected that the giving of betel leaf juice at the level of 5-10 $\mathrm{ml}$ in drinking water can be accepted by the body and is not responded as a foreign object, so that the 
resulted differential value of leukocytes is still at normal levels. Betel leaf contains flavonoid compounds as anti-inflammatory (Carolia and Noventi 2016), stimulates cortisol excretion (Sugito et al. 2012), and contains tannins as well as saponins as antibacterial (bactericidal) (Kursia et al. 2016), so that the immune system work less.

Based on the overall differential value of leucocytes, it could be assumed that the laying hens were in a healthy condition so that they did not make efforts to fight pathogenic bacteria or viruses entering their body. According to Sunu et al. (2021), cattle infected with bacteria will undergo health decline indicated by increases in white blood cells.

The results of the variance analysis showed that the giving of betel leaf juice did not have a significant effect $(p>0.05)$ on the H/L ratio of laying hens. The ratio value of heterophils and lymphocytes is an indicator of stress to the hot environment in chicken. According to Emadi et al. (2007), chicken blood H / L ratio is low (0.2) normal (0.5) and high (0.8). The higher the H/L ratio, the higher the heat stress level. This also means that the resistance of the chicken's body to hot environments is getting lower. This research showed that laying hens had a percentage of the $\mathrm{H} / \mathrm{L}$ ratio in each treatment within the normal range $(\mathrm{P} 0=0.45, \mathrm{P} 1=0.43, \mathrm{P} 2=0.45$, and $\mathrm{P} 3=0.44)$. These results indicated that laying hens in all treatments had resistance to hot environments.

This research showed that the lymphocyte concentration $(\mathrm{P} 0=60.67, \mathrm{P} 1=62.45, \mathrm{P} 2=61.72$, and $\mathrm{P} 3=62.39)$ in all treatments was higher than the heterophils concentration $(\mathrm{P} 0=27.04, \mathrm{P} 1=26.56, \mathrm{P} 2$ $=27.55$, and $\mathrm{P} 3=27.25)$. This means that the laying hens treated with betel leaf juice and the untreated have the potential to overcome the disease by forming antibodies.

\section{IV.CONCLUSION}

Based on the research results, it can be concluded that the giving of betel leaf juice at different levels does not affect the amount of hemoglobin levels, leukocyte differentials and the $\mathrm{H} / \mathrm{L}$ ratio in the blood of laying hens, however, these conditions are still in normal physiological conditions.

\section{REFERENCES}

[1]. Akramullah M. 2020. Identifikasi Keragaman Gen TGF- $\beta 2$ Serta Asosiasinya dengan Sifat Pertumbuhan dan Ketahanan Infeksi Bakteri Pada Ayam Tolaki. Tesis. Institut Pertanian Bogor. Bogor (ID).

[2]. Arjuna D, Saili T, Tasse AM. 2019. pengaruh pemberian air rebusan daun belimbing wuluh (Averrhoa bilimbi L.) terhadap jumlah leukosit ayam broiler yang mengalami cekaman panas. Indonesian Journal Of Animal Agricultural Science. 1(1): 28-33.

[3]. Cahyaningsih U, Malichatin H, Hedianto YE. 2007. Diferensial Leukosit pada Ayam Setelah Diinfeksi Eimeria Tenella dan Pemberian Serbuk Kunyit (Curcuma domestica) Dosis Bertingkat. Seminar Nasional Teknologi Peternakan dan Veteriner. IPB: Bogor (ID).

[4]. Carolia N, Noventi W. 2016. Potensi ekstrak daun sirih hijau (Piper betle L.) sebagai alternatif terapi Acne vulgaris. Jurnal Majority. 5(1): 140-145.

[5]. Chuammitri P, Redmond SB, Kimura K. 2011. Heterophil functional responses to dietary immunomodulators vary in genetically distinct chicken lines. Vet Immunol Immunop. 142: 219227.

[6]. Coles BH. 2006. Essential of Avian Medicine and Surgery. Blackwell Publishing: Iowa (US).

[7]. Damayanti R, Mulyono. 2003. Khasiat dan manfaat daun sirih: obat mujarab dari masa ke masa. Agromedia Pustaka; Jakarta (ID).

[8]. Emadi M, Kermanshahi H, Maraoufyan E. 2007. Effect of turmenic rhizome powder on the activity 
of some blood enzyme in broiler chicken. Int. J. Poulty. Sci. 6(1): 48-51.

[9]. Gaspersz V. 1994. Metode Rancangan Percobaan untuk Ilmu-ilmu Pertanian, Teknik dan Biologi. CV Armico: Bandung (ID).

[10]. Gerardo FQ Stephen JL, Todd FD, Darven W, Ken EL, Robert MJ. 2009. References limits for biochemical and hematological analytes of dairy cows one week beafor and one week after parturition. Can Vet J. 50(4): 383-388.

[11]. Harper HA, Roowell VW, Mayer PA. 1979. Terjemahan Muliawan, Biokimia Ed ke 17. Lange Medical Publ. Los Altos. California (US). Penerbit Buku Kedokteran E.G.C : Jakarta (ID).

[12]. Isroli S, Susanti E, Widiastuti T, Yudiarti, Sugiharto. 2009. Observasi beberapa variabel hematologis ayam Kedu pada pemeliharaan intensif. Prosiding Seminar Nasional Kebangkitan Peternakan. 1(7): 548-557.

[13]. Jain NC. 1993. Essential of Veterinary Hematology. Lea \& Febiger: Philadelphia (US).

[14]. Kursia S, Lebang JS, Nursamsiar N. 2016. Uji aktivitas antibakteri ekstrak etilasetat daun sirih hijau (Piper betle L.) terhadap bakteri Staphylococcus epidermidis. Indonesian Journal of Pharmaceutical Science and Technology. 3(2): 7277.

[15]. Mitchell EB, Johns J. 2008. Avian hematology and related disorders. Vet Clin Exot Anim. 11 : 501522.

[16]. Moreira LM, Behling BDS, Rodrigues RDS, Costa JAV, Soares LADS. 2013. Spirulina as a protein source in the nutritional recovery of Wistar rats. Brazilian Archives of Biology and Technology. 56(3): 447-456.

[17]. Mulyadi A, Triya ML, Barradillah A, Nuzul A, Muttaqien, Fakhrurrazi. 2015. Jumlah eritrosit dan nilai hematokrit sapi aceh dan sapi bali di Kecamatan Leumbah Seulawah Kabupaten Aceh Besar. J. Med. Vet, 9(2): 115-118.

[18]. Nicholas FW. 2004. Pengantar Genetika Veteriner. Pustaka Wira Usaha Muda: Bogor (ID).

[19]. Oppusunggu R. 2009. Pengaruh Pemberian Tablet Tambah Darah $(\mathrm{Fe})$ terhadap Produktifitas Kerja
Wanita Pensortir Daun Tembakau di PT.X. Kabupaten Deli Serdang. Tesis. Pascasarjana Universitas Sumatera Utara. Medan (ID).

[20]. Pahlepi R, Hafid H, Indi A. 2015. Bobot akhir persentase karkas dan lemak abdominal ayam broiler dengan pemberian ekstrak daun sirih (Piper betle L.) JITRO. 2(3): 1-6.

[21]. Rastogi SC. 1977. Essentials of Animal Physiology. Wiley Eastern Limited: New Delhi (IN).

[22]. Samour J. 2015. Diagnostic Value of Hematology in Clinical Avian Medicine. Volume II. Harrison GJ, Lightfoot TL. Spix Publishing: Florida (US).

[23]. Sugito, Rahmi E, Isa M. 2012. Respons HSP-70 dan kadar kortisol akibat pemberian kombinasi ekstrak jaloh dan kromium pada ayam broiler yang mengalami cekaman panas. Jurnal Kedokteran Hewan. 6 (2): 112-116.

[24]. Sunu P, Sunarti D, Mahfudz LD, Yunianto VD. 2021. Effect of synbiotic from Allium sativum and Lactobacillus acidophilus on hematological indices, antioxidative status and intestinal ecology of broiler chicken. Journal of the Saudi Society of Agricultural Sciences. 20(2): 103-110.

[25]. Syahrial A, Setyawati TR, Khotimah S. 2013. Tingkat kerusakan jaringan darah ikan mas (Cyprinus carpio) yang dipaparkan pada media Zn-Sulfat (ZnSO4). Protobiont. 2(3): 181-185.

[26]. Wibawan IWT, Soejoedono RS. 2013. Intisari Imunologi Medis. IPB Press: Bogor (ID).

\section{Cite this article as :}

Ning Ayu Dwi Tiya, Rusli Badaruddin, Muh Akramullah, Ali Bain, Natsir Sandiah, "Hemoglobin Level and Total Leukocyte Differential in Laying Hens Fed with Betel Leaf Juice (Piper betle Linn) ", International Journal of Scientific Research in Science, Engineering and Technology (IJSRSET), Online ISSN : 2394-4099, Print ISSN : 2395-1990, Volume 8 Issue 2, pp. 81-86, March-April 2021. Available at doi : https://doi.org/10.32628/IJSRSET218220 Journal URL : https://ijsrset.com/IJSRSET218220 